\title{
ЕФЕКТИВНІСТЬ ЛІКУВАННЯ ПРОЛЕЖНІВ У ПАЦІЄНТІВ ВІДДІЛЕННЯ ПАЛІАТИВНОЇ ДОПОМОГИ КОМУНАЛЬНОЇ 4-ї МІСЬКОЇ КЛІНІЧНОЇ ЛIКАРНІ М. ЛЬВОВА
}

\author{
I. В. Ометюх, Н. І. Рега, І. Я. Господарський \\ Комунальна 4-та міська клінічна лікарня м. Львова \\ ДвНЗ «Тернопільський державний медичний університет \\ імені І. Я. Горбачевського МОЗ Украӥни"
}

У статті описано ефективність лікування пролежнів у пацієнтів відділення паліативної допомоги. Показано низьку ефективність сучасних методів лікування пролежнів та запропоновано шляхи до її підвищення.

\section{THE EFFECTIVENESS OF PRESSURE ULCERS TREATMENT OF PATIENTS IN PALLIATIVE CARE DEPARTMENT OF LVIV MUNICIPAL $4^{\text {th }}$ CITY CLINICAL HOSPITAL}

\author{
I. V. Ometyuh, N. I. Reha, I. Ya. Hospodarskyi \\ Municipal $4^{\text {th }}$ City Clinical Hospital of Lviv \\ I. Horbachevsky Ternopil State Medical University
}

The article describes the pressure ulcers frequency among patients of palliative care department. There is low efficiency of modern methods of treatment of bedsores in hospital and the ways to improve it are offered

Вступ. Зростання технічної завантаженості умов існування сучасної людини призводить до збільшення абсолютної кількості техногенних травм і захворювань, які, в свою чергу, асоціюються з політравмою і затяжним перебуванням пацієнта в відділеннях реанімації та інтенсивної терапії. Характерні для таких хворих порушення свідомості, нестабільні переломи, знерухомлення і завантаженість моніторуючою апаратурою в сукупності зі спеціальними методиками здатні звести нанівець найбездоганнішу лікарську майстерність, якщо недоліки догляду призведуть до формування пролежнів.

Основні провокуючі фактори виникнення пролежнів нечисленні. Це тривалий тиск на прилеглі тканини понад 40 мм рт. ст. надмірна вологість і забруднення шкіри зазвичай виділеннями пацієнта, а також сили зсуву, що викликають тертя і декератинізацію поверхневого шару шкіри. Каталізатором патологічних процесів можуть виступати порушення нейротрофічної функції ЦНС і супутня патологія [1-4].

(ㄱ.В.Ометюх, Н. І. Рега, І. Я. Господарський, 2016
За багато років мало що змінилося в стані проблеми і в плані догляду, і з точки технічної оснащеності профілактики пролежнів. І до моменту написання галузевого стандарту, і зараз, широка медична громадськість не має вітчизняних статистичних даних (або доступу до них, якщо такі існують) за поширеністю пролежнів і сукупних економічних втратах, пов'язаних із ними. Тому ми в основному змушені звертатися до міжнародного досвіду [5]. Якщо більшість пацієнтів стаціонарів із пролежнями складають близько 16-17\%, то в установах із догляду їх частка коливається від 15 до 32 \% випадків. І це в країнах, де історично оснащеність і економіка на порядок більш продумана, ніж у нашій країні. Число випадків пролежнів у структурі внутрішньолікарняних інфекцій становить близько 7,5 \%. 3 різних причин летальність пацієнтів, які мають пролежневі виразково-некротичні дефекти шкіри і м'яких тканин, становить від 21 до 88,1% [1].

Основна частина. Метою нашої роботи було вивчення ефективності лікування пролежнів у пацієнтів відділення паліативної допомоги комунальної 4-ї міської клінічної лікарні м. Львова, які перебували

4 ISSN 2411-1597. МЕДСЕСТРИНСТВО. 2016. № 2 
на стаціонарному лікуванні у відділенні паліативної допомоги з 2008 року до жовтня 2015 року.

Серед усіх пацієнтів за цей період виявлено наявність пролежнів усього в 100 осіб.
Проаналізовано співвідношення кількості пацієнтів, які поступили у стаціонар з пролежнями і числа пацієнтів, у яких пролежні виникли під час перебування у стаціонарі. Отримані дані наведено в таблиці 1.

таблиця 1. Співвідношення кількості пацієнтів, які поступили у стаціонар з пролежнями і числа пацієнтів, у яких пролежні виникли під час перебування у стаціонарі

\begin{tabular}{|l|c|c|c|c|c|c|c|c|}
\hline \multicolumn{1}{|c|}{ Показник } & 2008 р. & 2009 р. & 2010 р. & 2011 р. & 2012 р. & 2013 р. & 2014 р. & $\begin{array}{c}2015 \text { р. } \\
\text { (9 місяців) }\end{array}$ \\
\hline $\begin{array}{l}\text { Кількість пацієнтів, які поступи- } \\
\text { ли у стаціонар з пролежнями }\end{array}$ & 2 & 7 & 10 & 13 & 17 & 21 & 18 & 12 \\
\hline $\begin{array}{l}\text { Кількість пацієнтів, у яких про- } \\
\text { лежні виникли під час перебу- } \\
\text { вання у стаціонарі }\end{array}$ & - & - & - & - & - & - & - & - \\
\hline
\end{tabular}

Як видно з таблиці 1, всі пацієнти з пролежнями уже мали їх до моменту госпіталізації, і у жодного з пацієнтів пролежні не виникли під час перебування у стаціонарі, що свідчить про якісний догляд за хворими в стаціонарі.

Проаналізовано ефективність лікування пролежнів. Після курсу комплексного лікування у частини пацієнтів (52 хворих, відповідно, 52 \%) спостерігались позитивні результати лікування, тобто повне та часткове (перехід у легшу стадію) загоєння пролежнів, а у решти 48 пацієнтів (відповідно, 48 \%) лікування не дало ефективного результату. Були відсутні негативні результати лікування, тобто погіршення стану пацієнта, перехід пролежнів у складнішу стадію. Отримані дані наведено в таблиці 1 та проілюстровано на рисунку 1.

Проаналізовано ефективність лікування пролежнів за роками. Отримані дані наведено в таблиці 2 та проілюстровано на рисунку 2.

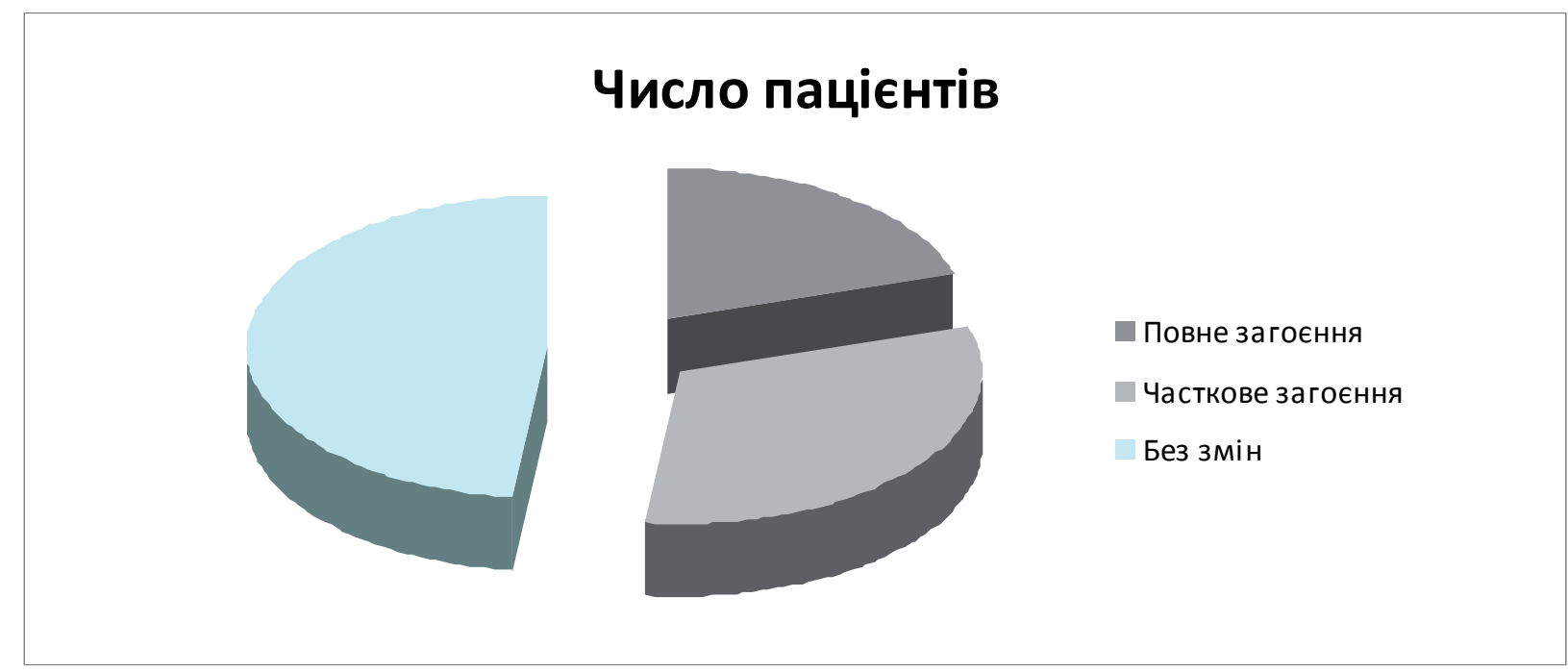

Puc. 1. Результати ефективності лікування пролежнів.

таблиця 2. Результати ефективності лікування пролежнів за роками

\begin{tabular}{|l|c|c|c|c|c|c|c|c|}
\hline \multicolumn{1}{|c|}{ Показник } & 2008 р. & 2009 р. & 2010 р. & 2011 р. & 2012 р. & 2013 р. & 2014 р. & $\begin{array}{c}2015 \text { р. } \\
\text { (9 місяців) }\end{array}$ \\
\hline $\begin{array}{l}\text { Загальна кількість хворих, } \\
\text { як мали пролежні }\end{array}$ & 2 & 7 & 10 & 13 & 17 & 21 & 18 & 12 \\
\hline $\begin{array}{l}\text { Кількість пацієнтів, в яких } \\
\text { було повне загоєння про- } \\
\text { лежнів }\end{array}$ & - & 2 & 3 & 3 & 4 & 3 & 2 & 3 \\
\hline $\begin{array}{l}\text { Кількість пацієнтів, в яких } \\
\text { було часткове загоєня } \\
\text { пролежнів }\end{array}$ & 2 & 3 & 5 & 4 & 3 & 5 & 6 & 4 \\
\hline
\end{tabular}




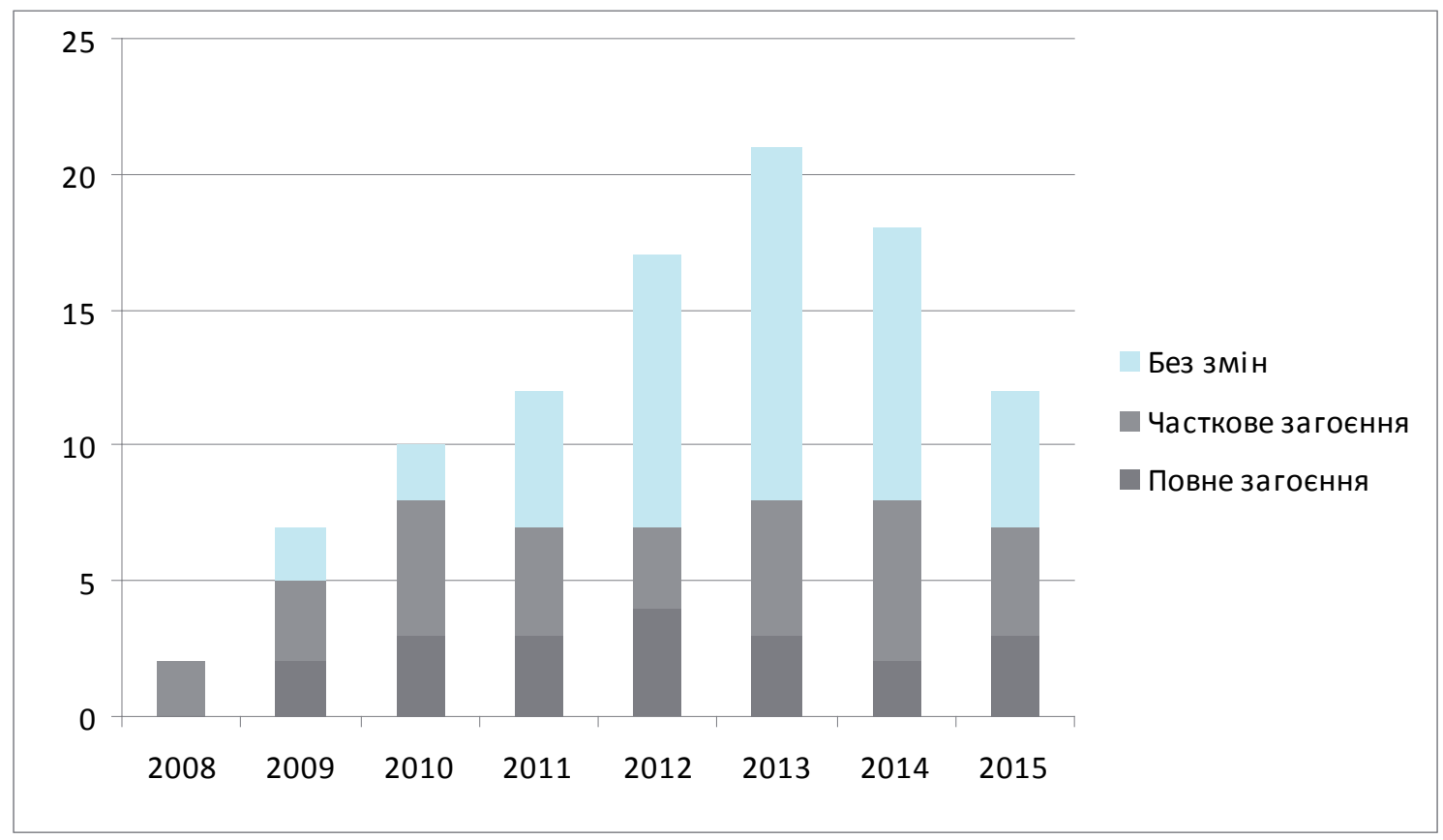

Puc. 2. Результати ефективності лікування пролежнів за роками.

Як видно з наведених результатів, більше ніж у половини випадків (52 \%) лікування пролежнів у стаціонарі було ефективним. Однак повного загоєння пролежнів вдалося досягти тільки у 20 \% випадків. Велика питома частка пацієнтів (48 \%) не мала ефекту від лікування. Вищенаведена тенденція зберігалась протягом усіх років дослідження. Тільки за останні роки питома частка пацієнтів із відсутністю ефекту від лікування дещо зменшується, що має деяке обнадійливе значення.

Наведені дані свідчать про складність і недостатню ефективність сучасних методів лікування пролежнів у стаціонарі та підкреслюють актуальність проблеми пошуку нових методів ефективного лікування пролежнів.

Пацієнти з пролежневими виразками І стадії не потребують хірургічного лікування, але наявність таких виразок має мобілізувати медичний персонал на профілактику прогресування процесу. Необхідно при цьому провести повторну оцінку стану здоров'я пацієнта, звертаючи особливу увагу на виявлення або виключення різних зовнішніх і внутрішніх факторів ризику розвитку пролежнів. Головним завданням лікування на цій стадії є захист рани від інфекції і подальшого впливу пошкоджуючих факторів. Окрім спеціальних заходів профілактики необхідне обов'язкове лікування будь-яких супутніх захворювань і синдромів, які спричиняють формування пролежнів різної локалізації (цукровий діабет, оклюзійні захворювання артерій), адекватне знеболювання і корекція водноелектролітного балансу $[2,9]$.

Провідним чинником в успішному консервативному лікуванні пролежнів є усунення тривалого безперервного тиску. Повертання пацієнта у ліжку через кожні 2 години може повністю попередити утворення пролежнів, але це дуже складно через завантаженість медичного персоналу. В зв'язку з цим у даний час великого поширення набули засоби, спрямовані на зниження сили тиску, а також забезпечують його переривчастість (пластикові шини, спеціальні ліжка, а також матраци, подушки і прокладки, які заповнюються піною, водою, гелем, повітрям або комбінацією цих матеріалів). Переривчастість фактора тиску з успіхом забезпечується системами з регульованим тиском і вібрацією, які зменшують локальний тиск на шкіру. Місцеве лікування сформованої пролежневої виразки включає ретельний туалет ділянки зміненої шкіри.

Починаючи з 70-х років XX століття, прицільно вивчалася ефективність різних препаратів для обробки виразок. Для цієї мети застосовували широкий спектр антисептиків, поки не з'явилися дані Rodeheaver G. (1988) про шкідливу дію на клітинні мембрани гексахлорофену, хлоргексидину та ін. Ці препарати порушують проникність клітинних мембран і пригнічують здатність клітин протистояти інвазії бактерій. Іноді, вбиваючи в рані лейкоцити, вони створюють сприятливі умови для розвитку мікрофлори. Тому при наявності чистої пролежневої виразки або запаленої

6 ISSN 2411-1597. МЕДСЕСТРИНСТВО. 2016. № 2 
поверхні шкіри туалет проводять фізіологічним розчином або препаратами, що не проявляють іонообмінні властивості. Після туалету при непорушеній цілісності шкіри здійснюють ретельне просушування ії поверхні і обробку засобами, що поліпшують місцевий кровообіг.

3 метою захисту запаленої шкіри від бактеріального фактора накладають клейові поліуретанові плівкові пов'язки (прозорі плівки), які забезпечують доступ кисню з атмосфери у виразку і випаровування вологи з виразкової поверхні. Разом з тим, досить маленькі пори пов'язки перешкоджають попаданню у виразку бактеріальної флори, а прозорість пов'язки дозволяє здійснювати візуальний контроль за станом шкіри.

II стадія $є$ перехідною і характеризується невеликими за площею поверхневими шкірними ушкодженнями. 3 точки зору хірургічного втручання при II стадії достатньо обмежитися туалетом рани в умовах перев'язочної. При цьому видаляють епідерміс у ділянках утворення міхурів, а також загальне забруднення.

Ділянки шкіри, позбавлені епідермісу, не слід обробляти іонообмінними антисептиками, для закриття змінених ділянок шкіри застосовуються спеціальні пов'язки. Для загоєння поверхневих ушкоджень шкіри також можуть бути використані:

- прозорі клейові плівкові пов'язки;

- вафельні гідроколоїдна або гідрогелева пов'язки;

- напівпроникні пінопластові пов'язки.

Необхідно віддавати перевагу пінистим напівпроникним пов'язкам, оскільки вони відповідають усім вимогам лікування пролежневих виразок. За виразкою потрібно ретельно спостерігати до відновлення епітеліального шару. У разі появи будь-яких ознак запалення хворому слід негайно призначити антибактеріальну терапію в поєднанні з більш частою зміною пов'язки.

III стадія пролежнів характеризується некротичним ураженням шкіри на всю глибину з залученням підшкірної жирової клітковини аж до фасції. Внаслідок коагуляційних процесів у центрі пролежень виглядає як кратер іноді темного кольору з набряклими і гіперемійованими навколишніми тканинами. Завданням лікування $є$ видалення некрозу хірургічним шляхом, очищення пролежневої виразки від гнійного ексудату та залишків некрозу, абсорбція відокремлюваного і запобігання висиханню рани.

Своєчасна некректомія і розтин гнійних запливів і порожнин дозволяють швидше очистити пролежень і зменшити інтоксикацію. Сформований при пролежнях вологий некроз не має відмежування і швидко поширюється на прилеглі тканини, які погано кровопостачаються. В цих умовах очікування самостійного відторгнення некротичних тканин є помилковим, тому доцільно проводити висічення тканин до появи капілярної кровотечі. Навіть при зовнішній картині сухого некрозу переважає змішана форма, коли під струпом виявляється вологий некроз і гнійне розплавлення. При змішаних формах оптимальним методом $\epsilon$ секвестраційна некректомія.

Основою подальшого лікування $є$ санація утвореної пролежневої виразки у стадії запалення з використанням місцевих антисептиків та інших препаратів. Окрім антибактеріальних препаратів для місцевого лікування пролежнів (бактерицидні та фунгіцидні засоби), застосовують:

а) некролітичні препарати (колагеназа, дезоксирибонуклеаза, трипсин, хімотрипсин, терилітин);

б) дегідратуючі - гіперосмолярні препарати;

в) засоби, що поліпшують мікроциркуляцію (пірікарбат, трібенозид);

г) протизапальні засоби (дексаметазон, гідрокортизон, преднізолон);

д) стимулятори репаративних процесів (метилурацил, вінілін, мазь каланхоє та ін.). Комплексне застосування цих препаратів з антибактерійною терапією дозволяє домогтися стабілізації стану хворого, купірування септичного стану і швидкого очищення виразки [1, 4, 6, 7].

Звичайно, вологе ведення ран не $є$ панацеєю. Багато дослідників вивчали клінічні проблеми, пов'язані зі значною або надмірною рановою ексудацією. Основними проблемами були протікання пов'язки та мацерація прилеглої неушкодженої шкіри, що погано переносилось пацієнтами [6, 7].

Сучасні перев'язувальні матеріали, включаючи гідроколоїди, детергенти, альгінати та гідрогелі, розроблялись та впроваджувались з метою забезпечення вологого середовища у рані, у той же час абсорбуючи чи іншим чином утримуючи надлишковий ексудат, проте їх використання було обмежене через низьку ефективність. Нарешті було запропоновано новий клас перев'язувальних матеріалів, що володіє здатністю утримувати надлишковий рановий ексудат [8].

Значна мікробна контамінація та інфікування ран становить подвійну проблему для клініцистів. Поперше, це негативно впливає на загоєння ран, особливо при супутніх проблемах з імунною системою, або 
у тих випадках, коли рана значно контамінована або погано кровопостачається. По-друге, контаміновані та інфіковані рани є потенційним джерелом так званого «перехресного інфікування» та розповсюдження антибіотикорезистентних штамів мікроорганізмів [9].

Антимікробні властивості срібла були відомі ще древнім єгиптянам, які клали срібні монети до глиняних глечиків з питною водою для запобігання інфекційним хворобам. При використанні срібла в антимікробних пов'язках іони срібла Ag++ безпосередньо зв'язуються з білками клітинних мембран бактерій, спричиняючи селективне пошкодження їх клітинної стінки. Окрім цього, іони Ag++ блокують шляхи клітинного дихання, через які мікроорганізми чинять свій руйнівний ефект [10].

Нова ранова пов'язка Aquacel, складається з нетканого волокна на основі Hydrofiber - натрію карбоксиметилцелюлози (Аквасель Гідрофайбер) та іонів срібла (Аквасель Ag). Вона здатна утримувати вологу безпосередньо всередині волокна, у той час як традиційні пов'язки утримують вологу в просторі між волокнами. Пряма абсорбція у волокна значно підвищує утримуючу здатність перев'язувального матеріалу в перерахунку на одиницю його маси. Цей процес, названий виробниками «гідроабсорбцією», надає значні переваги при вологому способі ведення ран. Зокрема, він забезпечує:

- зменшення або повне усунення бокового протікання;

- здатність абсорбувати значну кількість ранового ексудату;

- ексудат буде утримуватись пов'язкою навіть під тиском, наприклад, при стисканні бинтом чи шкарпеткою;

\section{ЛІТЕРАТУРА}

1. Климиашвили А. Д. Профилактика и лечение пролежней / А. Д. Климиашвили // Медицина неотложных состояний. - 2007. - № 5 (12). - С. 99-103.

2. Мусалатов Х. А. Лечение пролежней у больных с повреждением позвоночника и спинного мозга / Х. А. Мусалатов // Медицинская помощь. - 2002. № 3. - C. 22-28.

3. Басков А. В. Хирургическое лечение пролежней у больных со спинномозговой травмой / А. В. Басков // Вопросы нейрохирургии. - 2000. - № 1. - С. 30-33.

4. Климиашвили А. Д. Профилактика и лечение пролежней / А. Д. Климиашвили // Русский медицинский журнал. - 2004. - Т. 12, № 12. - С. 40-45.

5. Болгов И. В. Техническая сторона профилактики и лечения пролежней / И. В. Болгов, Д. В. Дорохов //
- володіє усіма перевагами, властивими гідроколоїдним пов'язкам [11].

У процесі виробництва перев'язувального матеріалу застосовано технологію, що сприяє вертикальній абсорбції, та ускладнює бокову, або латеральну абсорбцію. Зменшення бокового протікання дозволяє знизити або запобігти подразненню шкіри по краях виразки. Вертикальна абсорбція є головним чинником того, що волога утримується безпосередньо над відкритою рановою поверхнею відповідно до принципів вологого ведення ран $[6,12]$.

При абсорбції рідини у пов'язці створюється суцільна гелева маса, що може бути видалена при перев'язці з ранової поверхні єдиним блоком. Волога гелева маса тісно контактує з рановим ложем, при цьому не залишається вільного простору між рановою поверхнею та пов'язкою [13].

Висновки. Ефективному лікуванню пролежнів сприяють такі заходи, як рання активізація хворих у ліжку та палаті, піднімання головного кінця ліжка не вище 45 градусів, зменшення сили здавлювання та забезпечення переривчатості тиску, а також їх поєднання, виключення вологості, масаж, ЛФК.

Варто пам'ятати, що повноцінне харчування з достатнім вмістом білків, вітамінів дозволять зменшити ризик розвитку пролежнів у пацієнтів.

Вибір перев'язувального матеріалу $є$ вкрай важливим у лікуванні гострих та хронічних інфікованих ран. Цей вибір повинен враховувати такі складові як тип рани, фазу ранового процесу, місцеві умови у рані, у тому числі мікробна забрудненість, швидкість загоєння та кількість ексудату [14].

«Актуальные проблемы анестезиологии и реаниматологии. Освежающий курс лекций. Выпуск 16», Архангельск, 2010. - C. 217-223.

6. A non-comparative clinical evaluation of a new hydrofibre dressing Aquacel in patients with leg ulcers (poster presentation) / D. A. Brown, E. Hill, A. E. Nelson, C. V. Ruckley. In: G. W. Cherry, F. Gottrup, C. J. Lawrence, [et al] (eds). Proceedings of the 5th European Conference of Advances in Wound Management. London: Macmillan Magazines, 1996.

7. The diabetic foot and sodium carboxymethylcellulose: the healing of a chronic pressure sore / R. Cassino, A. Carusone, E. Ricci. In: Leaper, D., Cherry, G.W., Dealey, C. (eds). Proceedings of the 6th European Conference of Advances in Wound Management. London: Macmillan Magazines, 1997.

8 ISSN 2411-1597. МЕДСЕСТРИНСТВО. 2016. № 2 
8. Williams C. An investigation of the benefits of Aquacel Hydrofibre wound dressing / C. Williams // Br. J. Nurs. 1999. - Vol. 8 (10) - P. 676-680.

9. Silver Antimicrobial Dressings in Wound Management: A Comparison of Antibacterial, Physical, and Chemical Characteristics / David Parsons, Philip G. Bowler, Viv Myles, Samantha Jones // Wounds. - 2005 - Vol. 17, - Issue 8. P. $222-232$.

10. Duncan Stang. The use of Aquacel Ag in the management of diabetic foot ulcers. // Stang Duncan // The diabetic foot. $-2004$.

11. Robinson B. J. The use of hydrofibre dressing in wound management / B. J. Robinson // J. Wound Care. - 2000. Vol. 9(1) P. 32-34.
12. Lyndon M. J. The development of Aquacel hydrofibre dressings In: Kreig. T., Harding. K. (eds). Proceedings of Satellite Symposium, European Academy of Dermatology and Venerology. London: Churchill Communications, 1998.

13. Борисов В. С. Отчет о результатах клинического изучения раневых повязок «Аквасель Гидрофибер» и «Аквасель Аg» НИИ СП им. Н. В. Склифосовского // В. С. Борисов, С. В. Смирнов. - Москва, 2006.

14. Досвід використання високо абсорбуючих пов'язок на основі hydrofiber в лікуванні ран тулуба та нижніх кінцівок [Електронний ресурс] / І. А. Лурін, А. А. Кобірніченко, А. В. Сотников [та ін.] // Гнойная хирургия / Главный военный клинический госпіталь. - Режим доступу : http:// hirurg.org.ua/page/text/name=hydrofiber 